\title{
ANALISIS PENURUNAN MUKA TANAH DENGAN SMALL BASELINE SUBSET DIFFERENTIAL SAR INTERFEROGRAMS DI KOTA BANDAR LAMPUNG
}

\author{
Bagas Setyadi ${ }^{1}$, Rustadi $^{2}$ \\ ${ }^{1,2}$ Jurusan Teknik Geofisika, Fakultas Teknik Universitas Lampung \\ Jl. Prof. Soemantri Brodjonegoro No. 01, Bandar Lampung 35145 \\ Corresponding author: bagasetyadi@live.com \\ Manuscript received: June 3, 2019; revised: July 3, 2019; \\ Approved: July 16, 2019; available online: July 26, 2019
}

\begin{abstract}
Abstrak - Bandar Lampung adalah salah satu kota di Indonesia yang berpotensi mengalami penurunan muka tanah karena adanya ekstraksi air tanah, kegiatan pertambangan, alihfungsi lahan, dan kondisi geologi. Untuk itu dilakukan studi penurunan muka tanah dengan teknik SBAS, dikarenakan sangat kurangnya informasi mengenai gejala penurunan muka tanah di Kota Bandar Lampung. Dalam penelitian ini digunakan 15 data SAR dalam selang tahun 2006 - 2011 yang kemudian dikombinasikan untuk menghasilkan 40 interferogram yang kemudian diinversi sehingga menghasilkan data deformasi time-series dan kecepatan deformasi rata-rata. Akurasi kecepatan yang diperoleh dengan teknik SBAS sangat bergantung terhadap jenis tutupan lahan di daerah studi, selain itu diketahui pula bahwa penurunan muka tanah di Bandar Lampung rata-rata adalah 0,06 mm/tahun, yang dinilai cukup stabil dikarenakan tatanan geologi yang tidak memungkinkan untuk terjadinya proses konsolidasi secara masif. Beberapa area mengalami indikasi penurunan muka tanah $>5 \mathrm{~mm} /$ tahun yang diduga disebabkan oleh aktivitas tektonik dan kegiatan manusia (industri, pertambangan, ekstraksi air tanah, dan alihfungsi lahan) yang kemudian berimplikasi terhadap kerusakan struktur bangunan, terjadinya banjir rob di daerah pesisir, dan tanah longsor di daerah perbukitan.
\end{abstract}

\begin{abstract}
Bandar Lampung is one of the cities in Indonesia, which has a potential to land subsidence due to the extraction of ground water, mining, land conversion, and geological conditions. For that reason, carried out the study of land subsidence with SBAS technique, due to the very lack of information about the symptoms of land subsidence in Bandar Lampung. In this study, 15 SAR data in 2006 to 2011 used and then combined to produce 40 interferogram then inverted resulting in a time-series deformation and deformation speed average. Velocity precision obtained with SBAS technique is highly dependent on the type of land cover in the study area, but it is known that the average of land subsidence in Bandar Lampung is about $0.06 \mathrm{~mm} /$ year, which is considered quite stable due to the geological structure that does not allow for the occurrence of massive consolidation process. Several areas have indications of subsidence $>5 \mathrm{~mm}$ /year are suspected to be caused by tectonic activity and human activity (industrial, mining, extraction of groundwater, and land conversion), which then has implications for structural damage to buildings, flooding in coastal areas, and landslides in hilly areas.
\end{abstract}

Keywords: Differential Interferometric SAR (DInSAR); Small Baseline Subset (SBAS)

How to cite this article:

Setyadi, B. dan Rustadi. 2019. Analisis Penurunan Muka Tanah dengan Small Baseline Subset Differential SAR Interferograms di Kota Bandar Lampung. Jurnal Geofisika Eksplorasi, 5 (2) p.116-129.

doi: 10.23960/jge.v5i2.27 


\section{PENDAHULUAN}

Kota Bandar Lampung adalah sebuah kota di Indonesia yang menjadi pintu gerbang utama Pulau Sumatera, yang memiliki peran yang sangat penting selain sebagai Ibukota Provinsi Lampung. Selama satu dekade terakhir, kegiatan perekonomian Kota Bandar Lampung meningkat sehingga menimbulkan fenomena urbanisasi yang tinggi, yang menyebabkan kota ini memiliki jumlah penduduk mencapai 881.801 jiwa (BPS, 2010), yang pada tahun 1912 hanyalah berjumlah 18.753 jiwa. Pertumbuhan penduduk ini kemudian berimplikasi terhadap peningkatan konversi lahan yang cukup itensif (Utoyo, 2012).

Secara geologi Kota Bandar Lampung dilewati oleh beberapa struktur patahan dan pada beberapa daerah di kota ini memiliki formasi berumur holosen, dengan kondisi geologi tersebut dan banyaknya kegiatan pengeboran air tanah, pertambangan dan industri, serta kegiatan reklamasi, tentunya bisa menjadi faktor pendukung terjadinya penurunan muka tanah. Sehingga Bandar Lampung bisa menjadi salah satu daftar kota di Indonesia yang sangat rentan mengalami penurunan muka tanah akibat fenomena alam ataupun akibat perbuatan manusia. Hal ini tentunya dapat menimbulkan silent hazzard yang merusak infrastruktur perkotaan yang kemudian dapat saja menjadi gangguan terhadap stabilitas perekonomian dan kehidupan sosial.

Dalam studi penurunan muka tanah di suatu daerah, terdapat berbagai metode untuk mengetahui informasi penurunan muka tanah yaitu dengan metode sipat datar dan pengamatan GPS, namun karena keterbatasan cakupan spasial pada kedua metode tersebut, maka pola spasial penurunan muka tanah dan faktor-faktor yang menyebabkan penurunan muka tanah tetap tidak dapat diketahui. Oleh karena itu, metode DInSAR - SBAS dapat dipilih untuk mempelajari gejala penurunan muka tanah karena memiliki cakupan yang luas secara spasial maupun temporal serta memiliki akurasi yang tinggi.
DInSAR (Diffrential Interferometric Synthetic Aperture Radar) adalah salah satu teknik yang memanfaatkan beda fase antara dua data SAR yang memiliki waktu akuisisi yang berbeda pada daerah yang sama. Teknik ini dapat menghasilkan informasi spasial mengenai deformasi dengan akurasi yang tinggi (sub-sentimeter). Namun teknik DInSAR memiliki kekurangan dimana akurasinya dapat berkurang akibat propagasi atmosfer, interferensi medan topografi, dan dekorelasi temporal. Oleh karena hal tersebut, maka digunakan teknik SBAS (Small Baseline Subset) yang merupakan pengembangan dari teknik DInSAR yang mampu mereduksi gangguan tersebut.

\section{DAERAH STUDI}

Bandar Lampung merupakan Ibukota Provinsi Lampung yang merupakan daerah yang dijadikan sebagai pusat kegiatan pemerintahan, politik, pendidikan, kebudayaan dan juga sebagai pusat perekonomian. Kota Bandar Lampung terletak pada posisi $5^{\circ} 20^{\prime}-5^{\circ} 31^{\prime}$ LS dan $105^{\circ} 10^{\prime}-105^{\circ} 22^{\prime}$ BT. Kota ini terdiri dari 20 kecamatan dan 126 kelurahan (BPS 2015) dengan luas 197,22 km² (BPS, 2014).

Jumlah penduduk Bandar Lampung pada tahun 1912 hanya 18.753 jiwa, yang pada tahun 2010 berkembang menjadi 881.801 jiwa. Kota ini memiliki kepadatan penduduk rata-rata cukup tinggi, yaitu 2.979 jiwa/km² (BPS, 2011).

Secara umum penggunaan lahan di Kota Bandar Lampung didominasi daerah pemukiman penduduk, kemudian disusul dengan daerah perkebunan dan pesawahan serta ladang. Jumlah industri dan pemukiman penduduk meningkat secara masif dalam satu dekade (1999 - 2010), dimana untuk lahan industri sendiri meningkat sebesar 93,02\%, dan untuk daerah pemukiman meningkat sebesar $44 \%$. Peningkatan tersebut merupakan hasil dari konversi lahan kosong, rawa, dan hutan, yang dalam sepuluh tahun mengalami degradasi luasan lahan secara signifikan. 
Sebagian wilayah Kota Bandar Lampung merupakan daerah perbukitan, seperti Gunung Kunyit, Gunung Kelutum, Gunung Banten, Gunung Kucing, Gunung Camang, Gunung Balau, Gunung Kapuk, dan lain-lain. Dengan luas wilayah yang datar - landai meliputi $60 \%$ total wilayah, landai - miring meliputi 35\% total wilayah, dan sangat miring hingga curam meliputi $4 \%$ total wilayah.

Geomorfologi wilayah penelitian pada daerah pesisir tergolong sebagai pedataran pantai sempit dan perbukitan, dengan batuan dominan meliputi endapan aluvium dan rawa, batu gamping terumbu, dan endapan gunungapi muda berumur kwarter. Satuan geologi dan geomorfologi lingkungan wilayah penelitian ke arah pantai meliputi pedataran dan kaki perbukitan.

Stratigrafi daerah penelitian terbentuk pada Zaman Paleozoikum sampai dengan kwarter. Daerah ini terletak di belakang busur Pegunungan Barisan.

Terdapat beberapa litologi yang terletak di daerah penelitian, yaitu Formasi Lampung, formasi gunungapi muda, Formasi Tarahan, Formasi Kuarsit Sidodadi, formasi granit tak terpisahkan, dan formasi aluvium. Secara umum daerah Bandar Lampung didominasi oleh endapan batuan gunungapi muda seperti basal, andesit, dan tuff, yang terbentuk pada zaman tersier kwarter (Gambar 1).

Batuan yang tertua dan tersingkap di wilayah penelitian adalah batuan malihan (metamorf) yang terdiri dari sekis, kuarsit, pualam, genes dan migmatit, yang secara keseluruhan termasuk dalam Kompleks Gunungkasih (Pzg). Berdasarkan transek geologi Lembar Tanjung Karang (Mangga, dkk., 1993), Kompleks Gunungkasih diperkirakan sebagai basement di daerah penelitian.

\section{DATA DAN METODE PENELITIAN}

Dalam penelitian ini digunakan 15 raw data SAR ALOS-PALSAR yang diperoleh dari ASF ALASKA dalam polarisasi $\mathrm{HH}$ pada mode akuisisi descending di wilayah Kota Bandar Lampung yang diakuisisi pada akhir tahun 2006 sampai dengan awal tahun 2011. Data - data tersebut kemudian dikombinasikan sehingga didapatkan 40 pasangan data SAR (interferogram) (Gambar 2).

Filtering dilakukan untuk meningkatkan koherensi pada setiap interferogram. Filter Goldstein dipilih dalam penelitian ini karena filter ini bekerja lebih baik dalam meningkatkan visibilitas fringe dan dapat mengurangi efek derau akibat dekorelasi. Interferogram dengan phase ramp yang cukup kuat tidak diikutsertakan dalam penelitian ini dikarenakan dapat mengurangi reabilitas data. Proses eliminasi interferogram yang memiliki kualitas buruk dilakukan dengan screening secara manual.

Untuk mendapatkan nilai fase absolut pada interferogram, dilakukan proses phase unwrapping yang kemudian disusul dengan proses inversi yang dilakukan hanya pada pixel dengan nilai koherensi lebih dari 0,3 dengan mempertimbangkan nilai statistik koherensi pada seluruh interferogram, dimana jika digunakan nilai batas koherensi lebih besar dari 0,3 akan banyak informasi yang hilang, dan jika digunakan nilai koherensi kurang dari 0,3 akan mengurangi SNR dari interferogram.

Dalam penelitian ini dilakukan juga koreksi kesalahan DEM dan atmospheric filtering dengan low-pass $1200 \mathrm{~m}^{2}$ dan highpass 365 hari yang diharapkan akan meningkatkan relevansi data.

\section{HASIL PENELITIAN}

Hasil pengolahan data SAR dengan menggunakan teknik SBAS pada penelitian ini menghasilkan informasi mengenai kecepatan deformasi pada arah Line of Sight (LOS) di daerah Kota Bandar Lampung dengan resolusi data sebesar $20 \times 20$ meter. Analisis kecepatan deformasi pada penelitian ini dibatasi hanya pada daerah yang memiliki akurasi kecepatan $<7$ $\mathrm{mm} /$ tahun serta koherensi temporal $\left(C_{\text {temp }}\right)$ 
$>0,7$. Kecepatan deformasi yang dihasilkan mengacu pada arah LOS yang terreferensikan pada satu titik referensi yang merupakan daerah yang stabil. Kecepatan deformasi pada arah LOS memiliki nilai positif (skala warna hijau) untuk merepresentasikan deformasi relatif yang mengarah ke satelit (uplift) dan nilai kecepatan LOS negatif (skala warna merah) untuk merepresentasikan deformasi relatif menjauhi arah satelit (subsidence).

\subsection{Reabilitas Data}

Kesalahan dalam proses unwrapping, adanya derau pada interferogram, serta kesalahan dalam pemrosesan data dapat menyebabkan pola deformasi yang tidak konsisten. Indeks kualitas dari data disebut juga sebagai temporal coherence factor $\left(\mathrm{C}_{\text {temp }}\right)$. Sehingga dengan menganalisis nilai $\mathrm{C}_{\text {temp }}$ maka dapat diketahui pixel mana saja yang memiliki informasi yang reliabel.

Berdasar pada Gambar 3, nilai $C_{\text {temp }}$ sangat dipengaruhi oleh jenis tutupan lahan di daerah studi, dimana pada daerah yang dinamis (lahan pertanian dan hutan) cenderung memiliki nilai $C_{\text {temp }}$ yang rendah, sedangkan pada daerah pemukiman penduduk yang cenderung statis memiliki $C_{\text {temp }}$ yang tinggi.

Akurasi dari hasil pengukuran deformasi di daerah studi diperoleh dari beberapa parameter seperti koherensi dan panjang gelombang yang kemudian dikalkulasi sehingga akan diperoleh estimasi akurasi kecepatan, dimana semakin besar nilainya maka akan semakin rendah akurasi pengukurannya dan begitupun sebaliknya. Estimasi akurasi kecepatan dikalkulasi dengan persamaan berikut

$$
\sigma=\sqrt{\frac{1-\gamma^{2}}{2 \gamma^{2}}} \frac{\lambda}{4 \pi}
$$

dimana $\sigma$ adalah akurasi pengukuran, $\gamma$ adalah interferomatric coherence, dan $\lambda$ adalah panjang gelombang yang digunakan. Adapun representasi dari akurasi kecepatan dari data ditunjukkan pada Gambar 4.
Akurasi kecepatan $(\sigma)$ bernilai cukup tinggi (20 - $50 \mathrm{~mm} /$ tahun) pada daerah yang dinamis (daerah bervegetasi tinggi). Karena nilai $\sigma$ tersebut tidak cukup reliabel dalam hal pengukuran penurunan muka tanah yang berada dalam orde milimeter, maka tidak ada informasi yang relevan yang dapat diperoleh pada daerah-daerah tersebut.

Sedangkan untuk daerah urban, nilai $\sigma$ berkisar antara $0-0,7 \mathrm{~mm} /$ tahun. Akurasi ini cukup tinggi mengingat daerah urban cenderung statis (tidak mengalami perubahan yang cukup signifikan) dari waktu ke waktu. Oleh sebab itu hasil pengukuran SBAS yang memiliki reabilitas yang tinggi sebagian besar diperoleh pada daerah ini.

\subsection{Analisis Penurunan Tanah}

Untuk proses analisis pada penelitian ini digunakan dua pendekatan, yang pertama dilakukan investigasi terhadap indikasi penurunan muka tanah pada skala regional, dengan cara mengidentifikasi area yang memiliki indikasi penurunan tanah yang tinggi berdasarkan hasil pengukuran SBAS. Kemudian dilakukan analisis pada skala lokal yang bertujuan untuk membatasi pembahasan hanya pada area tertentu untuk mengurangi kekompleksitasan dari kondisi geologi bawah permukaan dan juga faktor penyebab penurunan muka tanah yang cukup bervariasi (Gambar 4).

\subsection{Korelasi Terhadap Geologi}

Batas litologi di wilayah Kota Bandar Lampung ternyata tidak berkorelasi dengan pola penurunan muka tanah. Hal ini disebabkan karena secara regional kondisi geologi di daerah studi cenderung seragam, yaitu tersusun dari batuan gunungapi kwarter (basal, andesit, dan tuff) yang cenderung tidak mengalami konsolidasi. Selain itu pada kenyataannya di lapangan, tatanan geologi di Bandar Lampung sebenarnya cukup kompleks dan bervariasi antara satu tempat dengan tempat lainnya (Gambar 5).

Beberapa patahan yang berada di wilayah Kota Bandar Lampung tidak 
menyebabkan pola deformasi yang cukup kontras, hal ini disebabkan karena tidak adanya aktivitas kegempaan yang terrekam selama tahun 2006 - 2011 (USGS).

Namun walapun begitu ada beberapa segmen patahan yang terindikasi menyebabkan penurunan muka tanah. Hal ini dibuktikan dengan hasil irisan penampang geologi dan data deformasi pada Gambar 5 yang terrepresentasikan pada profil yang ditunjukkan dalam Gambar 6.

Profil a - a' merupakan irisan pada segmen Sesar Panjang - Lampung yang bersesuaian dengan arah aliran Sungai Way Halim. Zona patahan ini terindikasi menyebabkan penurunan muka tanah di sebelah Barat. Tepat pada area di sekitar patahan terlihat adanya ketidakmenerusan kecepatan deformasi yang menunjukkan adanya aktifitas di zona patahan ini.

Penurunan muka tanah di daerah patahan ini didukung pula oleh kondisi geologi di sebelah Barat patahan yang tersusun dari batuan yang kurang kompak (tuff) dibandingkan dengan batuan di sebelah Timur (andesit - basal) yang kemudian me-nyebabkan daerah di sebelah Timur mengalami penurunan muka tanah.

Profil b - b' yang menunjukkan penurunan yang bervariasi, namun cenderung terjadi hanya pada daerah di sebelah Barat zona patahan, sedangkan di sebelah Timurnya cenderung naik (uplift). Namun karena kondisi geologinya yang cenderung homogen, selisih kecepatan deformasi tidak bernilai signifikan.

\subsection{Indikasi Penurunan Muka Tanah}

Dalam penelitian ini dilakukan analisis hanya kepada enam daerah observasi yang terindikasi kuat mengalami penurunan muka tanah (rata-rata $>5 \mathrm{~mm} /$ tahun dalam area 200 $\times 200$ meter).

\subsubsection{Campang Raya, Tanjungkarang Timur (A)}

Hasil observasi pada daerah Tanjung Karang Timur menunjukkan daerah yang terindikasi mengalami penurunan muka tanah dengan kecepatan rata-rata 9 $\mathrm{mm} /$ tahun. Proses penurunan tanah pada daerah ini berkorelasi terhadap penggunaan lahan di daerah ini, dimana pada daerah ini berdiri suatu kawasan industri dan area pemukiman padat penduduk.

Perkembangan kawasan industri dan pemukiman di daerah ini menyebabkan penambahan beban yang dipikul oleh lapisan tanah (akibat beban struktur) dan juga terjadi peningkatan penggunaan airtanah (dengan asumsi peningkatan jumlah penduduk dan industri dianggap berbanding lurus terhadap konsumsi airtanah), seperti yang ditunjukkan dari Gambar 7 yang menunjukkan perkembangan kawasan industri dan pemukiman penduduk yang cukup masif dalam kurun waktu 11 tahun (2001 - 2012).

\subsubsection{Gunung Camang, Kedamaian (B)}

Proses penurunan muka tanah lebih dari $5 \mathrm{~mm} /$ tahun teriindikasi pada titik $\mathrm{C}$ yang merupakan kawasan Gunung Camang, yang secara rata-rata mengalami penurunan muka tanah sebesar 7,4 mm/tahun.Penurunan muka tanah di Gunung Camang diduga disebabkan oleh gangguan akibat kegiatan manusia berupa kegiatan penambangan bahan galian tipe - C di sekitar lereng Gunung Camang yang menimbulkan getaran dan juga perubahan sudut kemiringan yang menjadi lebih terjal. Terjadi pula pengubahan lahan secara intensif pada puncak Gunung Camang yang merupakan daerah konservasi menjadi daerah hunian (Gambar 8).

Penurunan muka tanah sangat dimungkinkan walaupun secara notabene Gunung Camang tersusun dari batuan cadas (tuff - tuffit), karena penurunan muka tanah akibat kegiatan penambangan dan pengubahan lahan secara itensif dapat berdampak pada segala jenis batuan (Chaussard, 2013).

\subsubsection{Kangkung, Telukbetung Selatan (C) Indikasi penurunan muka tanah terdeteksi pada daerah padat penduduk di Pasar Kangkung, Telukbetung Selatan, dengan pola spasial yang terkarakterisasi kurang dari $10 \mathrm{~km}^{2}$ (patchy) (Gambar 9).}


Daerah ini mengindikasikan adanya penurunan muka tanah dengan kecepatan rata-rata $14,7 \mathrm{~mm} /$ tahun. Padatnya penduduk (9.251 jiwa $\left./ \mathrm{km}^{2}\right)$ tentunya sebanding dengan konsumsi airtanah di daerah ini, dimana untuk kebutuhan airtanah, masyarakat memanfaatkan sumur gali dengan kedalaman 8 - 12 meter (Syafriadi, dkk., 2014) dan juga beberapa sumur bor dengan debit rata-rata 150 liter/menit (CV. Kani Mitra Mandiri pada tahun 2006 dalam Saputra, dkk, 2016) yang diindikasikan dengan adanya intrusi air laut dari hasil analisis sumur gali dan sumur bor di daerah ini, dimana sumur yang berada pada jarak 140 - 500 meter dari pantai terindikasi mengalami intrusi air laut dengan salinitas antara 0,04 ppm-0,32 ppm.

\subsubsection{Sukaraja, Telukbetung Selatan (D)}

Area reklamasi ini merupakan timbunan material hasil eksploitasi Gunung Camang (Wahyuni, 2006), dan karena daratan hasil reklamasi umumnya masih belum terkonsolidasi dan terkompaksi dengan baik, sehingga dari sifat fisik dan mekanika material timbunan tersebut dapat berpotensi mengalami penurunan tanah dengan kecepatan penurunan yang besar, dan berdasarkan hasil pengukuran SBAS, penurunan muka tanah pada daerah ini ratarata mencapai 30,5 mm/tahun.

\subsubsection{Bakung, Telukbetung Barat (E)}

Indikasi penurunan muka tanah di sebelah Baratdaya Kota Bandar Lampung menunjukkan sesuatu pola penurunan muka tanah yang menarik pada suatu daerah pemukiman di Kelurahan Bakung Kecamatan Teluk Betung Barat. Pada daerah ini ditemukan anomali penurunan muka tanah yang sangat kontras sekali dengan daerah disekitarnya yang cenderung stabil. Daerah ini mengalami penurunan muka tanah dengan kecepatan rata-rata 15,3 mm/tahun. Berdasarkan hasil observasi di lapangan, daerah ini memiliki morfologi sinklin yang terletak diantara tiga daerah perbukitan dan sebagaian daerah di bagian Utara merupakan rawa-rawa (Gambar 10).

\subsubsection{Beringin Raya, Kemiling (F)}

Penurunan rata-rata di daerah ini berdasarkan pengukuran SBAS adalah sebesar 16 mm/tahun. Karena pada daerah didominasi oleh lapisan kaya lempung, maka secara mekanika tanah hal inilah yang diduga sebagai penyebab penurunan muka tanah di daerah ini. Tanah yang bersifat kohesif (tanah kaya lempung) sangat mungkin mengalami penurunan muka tanah, karena lapisan ini sangat sensitif terhadap perubahan kandungan air (soil moisture). Hal ini membuatnya berekspansi ketika lembab/basah, dan kemudian menyusut ketika kering (volumetric change).

\subsection{Kompilasi Faktor}

Hasil analisis dari enam daerah yang terindikasi mengalami penurunan muka tanah yang sudah dibahas pada pada bagian sebelumnya dirangkum dalam bagian ini yang kemudian disajikan dalam Tabel 1.

\subsection{Implikasi Penurunan Muka Tanah}

Penurunan muka tanah di Kota Bandar Lampung terjadi karena proses alam (aktifitas tektonik) dan juga akibat dari kegiatan manusia, seperti kegiatan perindustrian, pertambangan, ekstraksi airtanah, serta akibat pengembangan kawasan. Faktor - faktor tersebut mempengaruhi penurunan muka tanah secara mandiri ataupun secara stimultan, dan sebagian hal tersebut dipicu oleh masalah konversi lahan di Kota Bandar Lampung yang terjadi akibat adanya inkonsistensi dalam pemanfaatan dan pengendalian pemanfaatan ruang di Kota Bandar Lampung (Wahyuni, 2006).

Permasalahan konversi lahan di Kota Bandar Lampung yang disebabkan karena keterbatasan lahan, sementara tuntutan pemenuhan kebutuhan lahan semakin meningkat secara cepat, mengakibatkan kawasan-kawasan terbuka atau kawasan konservasi yang dikonversi untuk aktivitas yang secara ekonomi jauh lebih menguntungkan, yaitu aktivitas pertambangan, industri, dan reklamasi tanpa 
memperhitungkan resiko bencana yang mungkin terjadi.

Salah satunya implikasi tersebut adalah penurunan muka tanah di pesisir Kota Bandar Lampung sebesar 5 - $25 \mathrm{~mm} / \mathrm{tahun}$, yang juga terjadi peningkatan muka air laut global sebesar $3-10 \mathrm{~mm} /$ tahun. Hal ini kemudian menyebabkan beberapa kawasan yang berbatasan langsung dengan laut dengan morfologi dataran rendah akan mengalami banjir rob pada saat laut pasang, terutama di area sekitar proyek reklamasi (Gambar 11).

Selanjutnya terindikasinya penurunan muka tanah akibat ketidakstabilan lereng di daerah eksploitasi Gunung Camang, ternyata menyebabkan tanah longsor pada perumahan penduduk di Kelurahan Bumi Raya (Pecoh Raya) pada tanggal 13 Oktober 2013 yang terletak persis di Selatan lereng Gunung Camang.

Penurunan tanah juga menyebabkan kerusakan struktur bangunan seperti yang ditemukan pada daerah-daerah yang terindikasi mengalami penurunan muka tanah yang bila tidak tindak lanjuti maka akan menyebabkan peningkatan luasan dari daerah yang mengalami kerusakan struktur bangunan dan juga tingkat kerusakan yang ditimbulkan.

\section{KESIMPULAN}

Jenis penggunaan lahan sangat mempengaruhi reabilitas data, semakin dinamis suatu area maka informasi kecepatan deformasi yang terukur dengan teknik SBAS menjadi semakin tidak relevan untuk pengukuran gejala deformasi dalam sekala milimeter.

Teknik SBAS cukup reliabel untuk mengetahui gejala deformasi di Kota Bandar Lampung yang ditunjukkan oleh bukti-bukti kerusakan struktur bangunan dan jalan raya, serta jejak penurunan muka tanah pada tiang jaringan listrik.

Indikasi penurunan muka tanah tidak merata di semua tempat, namun secara ratarata Kota Bandar Lampung mengalami penurunan muka tanah dengan kecepatan 0,06 $\mathrm{mm} /$ tahun dengan trend yang cenderung linier.

Penurunan muka tanah dengan kecepatan lebih dari $5 \mathrm{~mm} /$ tahun secara spasial memiliki dua pola, yaitu patchy $(<10$ $\mathrm{km}^{2}$ ) pada daerah pesisir Teluk Lampung dan di Kecamatan Kemiling, serta lokal (10 - $100 \mathrm{~km}^{2}$ ) di bagian Timur Kota Bandar Lampung, yaitu di daerah Tanjung Karang Timur.

Penurunan muka tanah di Kota Bandar Lampung terjadi karena proses alam (aktivitas tektonik) dan juga akibat kegiatan manusia (industri, pertambangan, ekstraksi air tanah, dan alihfungsi lahan). Faktorfaktor tersebut mempengaruhi kecepatan penurunan muka tanah secara individual ataupun secara stimultan.

\section{DAFTAR PUSTAKA}

BPS (Badan Pusat Statistik), 2010, Sensus Penduduk 2010.

BPS (Badan Pusat Statistik) Provinsi Lampung, 2011, Lampung Dalam Angka 2011.

BPS (Badan Pusat Statistik) Kota Bandar Lampung, 2014, Luas Wilayah Kota Bandar Lampung menurut Kecamatan Tahun $2014\left(\mathrm{~km}^{2}\right)$.

BPS (Badan Pusat Statistik) Provinsi Lampung, 2015, Jumlah Kecamatan dan Desa/Kelurahan Provinsi Lampung Menurut Kabupaten/Kota, 2013-2015.

Chaussard, E., Amelung, F., Abidin, H., dan Sang-Hong, 2013, Sinking Cities in Indonesia: ALOS PALSAR Detects Rapid Subsidence Due to Groundwater and Gas Extraction, Elsevier Remote Sensing of Environment: 128 (2013) 150-161.

Mangga, S. Andi, Amiruddin, Suwarti, T., Gafoer, S., dan Sidarto, 1994, Geologi Lembar Tanjungkarang, Sumatera, 
Bandung: Pusat Penelitian dan Pengembangan Geologi.

Saputra, D., Purwadi, O.T., dan Sumiharni, 2016, Studi Air Tanah Berbasis Geographics Information System (GIS) di Kota Bandar Lampung, JRSDD, Edisi September 2016, Vol. 4, No. 3, Hal:469 - 480 (ISSN:23030011).

Utoyo, Bambang, 2012, Dinamika Penggunaan Lahan di Wilayah Perkotaan (Studi di Kota Bandar Lampung), FISIP UNILA: Seminar Hasil-Hasil Penelitian dan Pengabdian Kepada Masyarakat.

Wahyuni, Endang, 2006, Analisis Keterkaitan Permasalahan Tata Ruang Dengan Kinerja Perkembangan Wilayah (Studi Kasus Kota Bandar Lampung), Bogor: Sekolah Pascasarjana IPB. 
Tabel 1. Hasil analisis daerah yang terindikasi mengalami penurunan muka tanah.

\begin{tabular}{|c|c|c|c|c|c|c|c|}
\hline Lokasi & $\begin{array}{c}\text { Kecepatan } \\
\text { Penurunan } \\
\text { muka tanah } \\
\text { rata-rata } \\
\text { (mm/tahun) }\end{array}$ & $\begin{array}{l}\text { Pola } \\
\text { spasial }\end{array}$ & Geologi & $\begin{array}{c}\text { Korelasi } \\
\text { terhadap } \\
\text { kondisi } \\
\text { geologi }\end{array}$ & $\begin{array}{l}\text { Penggunaan } \\
\text { lahan }\end{array}$ & $\begin{array}{c}\text { Korelasi } \\
\text { terhadap } \\
\text { penggunaan } \\
\text { lahan }\end{array}$ & $\begin{array}{l}\text { Penyebab } \\
\text { (dugaan) } \\
\text { penurunan } \\
\text { muka tanah }\end{array}$ \\
\hline $\begin{array}{l}\text { Campang } \\
\text { Raya, } \\
\text { Tanjung } \\
\text { karang } \\
\text { Timur (A) }\end{array}$ & 9 & lokal & $\begin{array}{l}\text { batuan } \\
\text { ektrusif } \\
\text { dan intrusif }\end{array}$ & $x$ & $\begin{array}{l}\text { industri dan } \\
\text { pemukiman }\end{array}$ & $\sqrt{ }$ & $\begin{array}{l}\text { ekstraksi air } \\
\text { tanah oleh } \\
\text { kegiatan } \\
\text { industri dan } \\
\text { beban } \\
\text { struktur }\end{array}$ \\
\hline $\begin{array}{l}\text { Gunung } \\
\text { Camang, } \\
\text { Kedamaian } \\
\text { (B) }\end{array}$ & 7,4 & patchy & $\begin{array}{l}\text { batuan } \\
\text { ekstrusif } \\
\text { (tuff - } \\
\text { tuffit) }\end{array}$ & $x$ & $\begin{array}{l}\text { pemukiman } \\
\text { dan } \\
\text { pertambangan }\end{array}$ & $\sqrt{ }$ & $\begin{array}{l}\text { kegiatan } \\
\text { pertambangan } \\
\text { dan ekstraksi } \\
\text { air tanah } \\
\end{array}$ \\
\hline $\begin{array}{l}\text { Pasar } \\
\text { Gudang } \\
\text { Lelang, } \\
\text { Telukbetung } \\
\text { Selatan (C) }\end{array}$ & 14,6 & patchy & $\begin{array}{l}\text { batuan } \\
\text { ekstrusif } \\
\text { dan } \\
\text { sedimen } \\
\text { (sandstone) }\end{array}$ & $\sqrt{ }$ & $\begin{array}{l}\text { perumahan } \\
\text { dan area } \\
\text { perdagangan } \\
\& \text { jasa }\end{array}$ & $\sqrt{ }$ & $\begin{array}{l}\text { ekstraksi air } \\
\text { tanah oleh } \\
\text { penduduk dan } \\
\text { kegiatan } \\
\text { usaha }\end{array}$ \\
\hline $\begin{array}{l}\text { Area } \\
\text { reklamasi, } \\
\text { Sukaraja, } \\
\text { Telukbetung } \\
\text { Selatan (D) }\end{array}$ & 30,5 & patchy & alluvial & $\sqrt{ }$ & industri & $\sqrt{ }$ & $\begin{array}{l}\text { konsolidasi } \\
\text { material } \\
\text { timbunan }\end{array}$ \\
\hline $\begin{array}{l}\text { Bakung, } \\
\text { Telukbetung } \\
\text { Barat (E) }\end{array}$ & 15,5 & patchy & $\begin{array}{l}\text { batuan } \\
\text { ekstrusif } \\
\text { dan peat }\end{array}$ & $\sqrt{ }$ & $\begin{array}{l}\text { perumahan } \\
\text { dan rawa- } \\
\text { rawa }\end{array}$ & $\sqrt{ }$ & $\begin{array}{l}\text { dekomposisi } \\
\text { material } \\
\text { organik dan } \\
\text { beban } \\
\text { struktur }\end{array}$ \\
\hline $\begin{array}{l}\text { Beringin } \\
\text { Raya, } \\
\text { Kemiling } \\
\text { (F) }\end{array}$ & 16 & patchy & $\begin{array}{l}\text { batuan } \\
\text { ekstrusif } \\
\text { dan } \\
\text { lempung }\end{array}$ & $\sqrt{ }$ & $\begin{array}{l}\text { perumahan } \\
\text { dan lahan } \\
\text { kosong }\end{array}$ & $x$ & $\begin{array}{l}\text { penyusutan } \\
\text { volume pada } \\
\text { lapisan } \\
\text { lempung }\end{array}$ \\
\hline
\end{tabular}



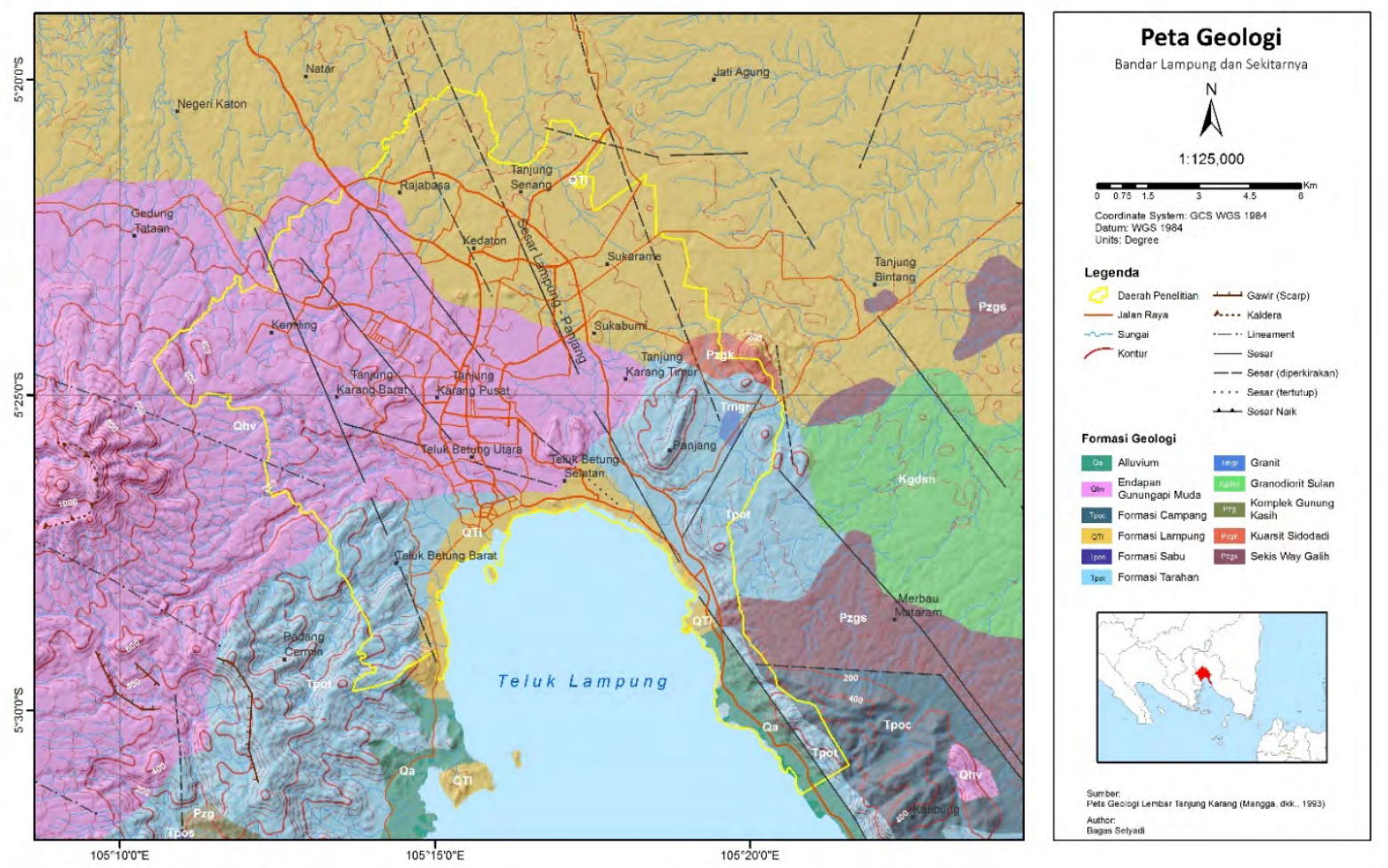

Gambar 1. Geologi daerah Kota Bandar Lampung.

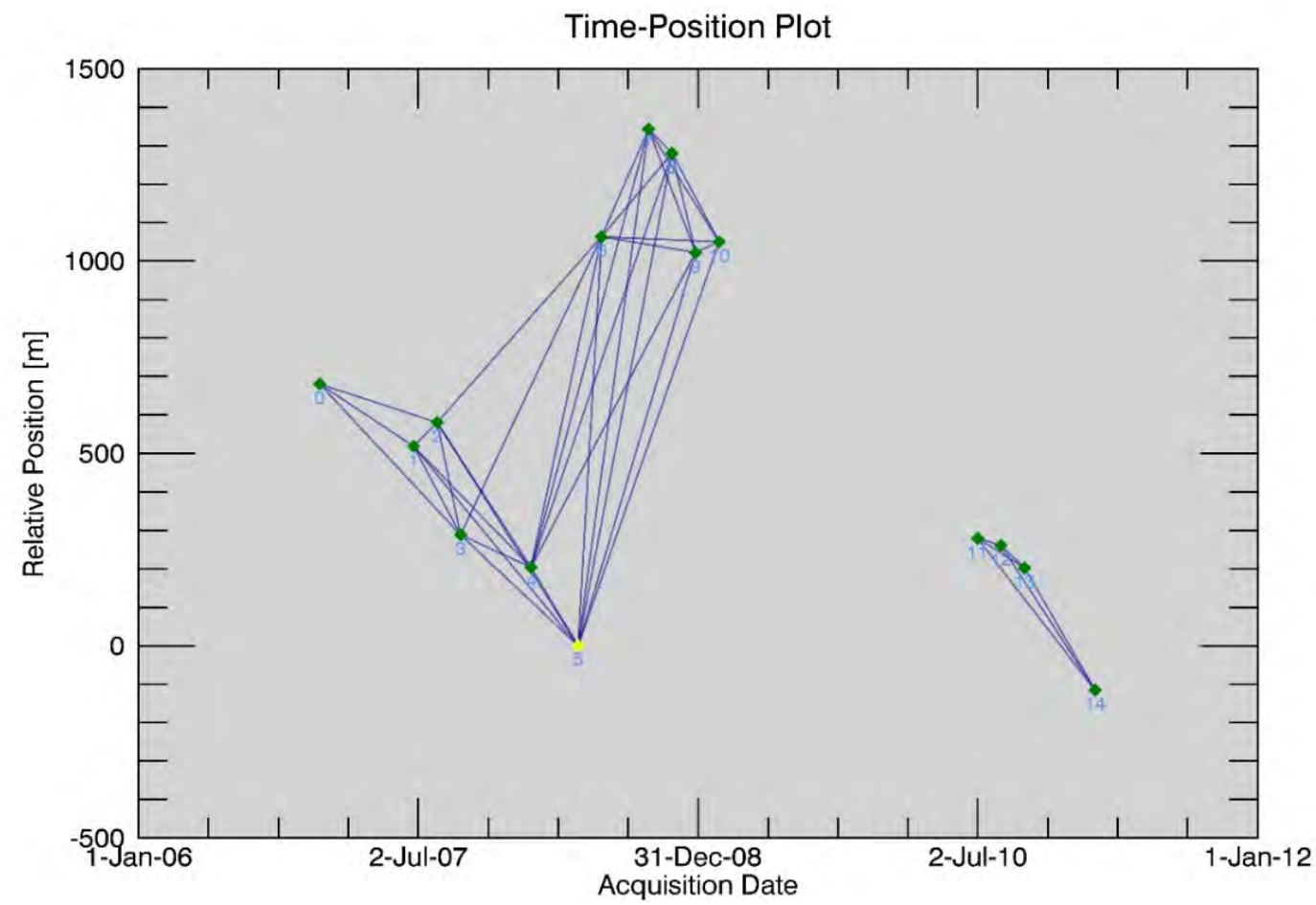

Gambar 2. Jaringan interferogram. Setiap titik pada diagram time-position plot merupakan data SAR dan setiap garis yang menghubungkan antar titik tersebut adalah sebuah interferogram. 


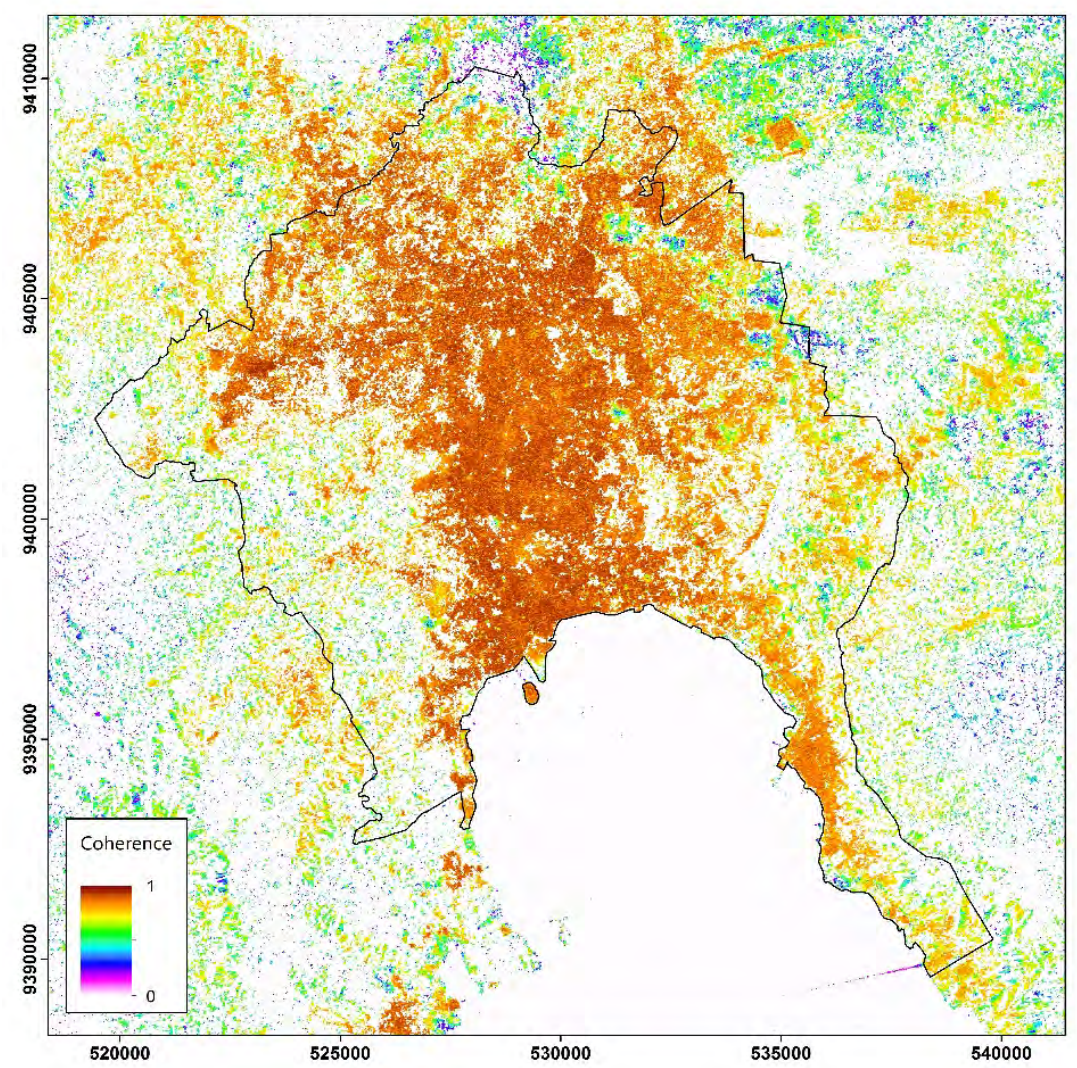

Gambar 3. Peta koherensi temporal

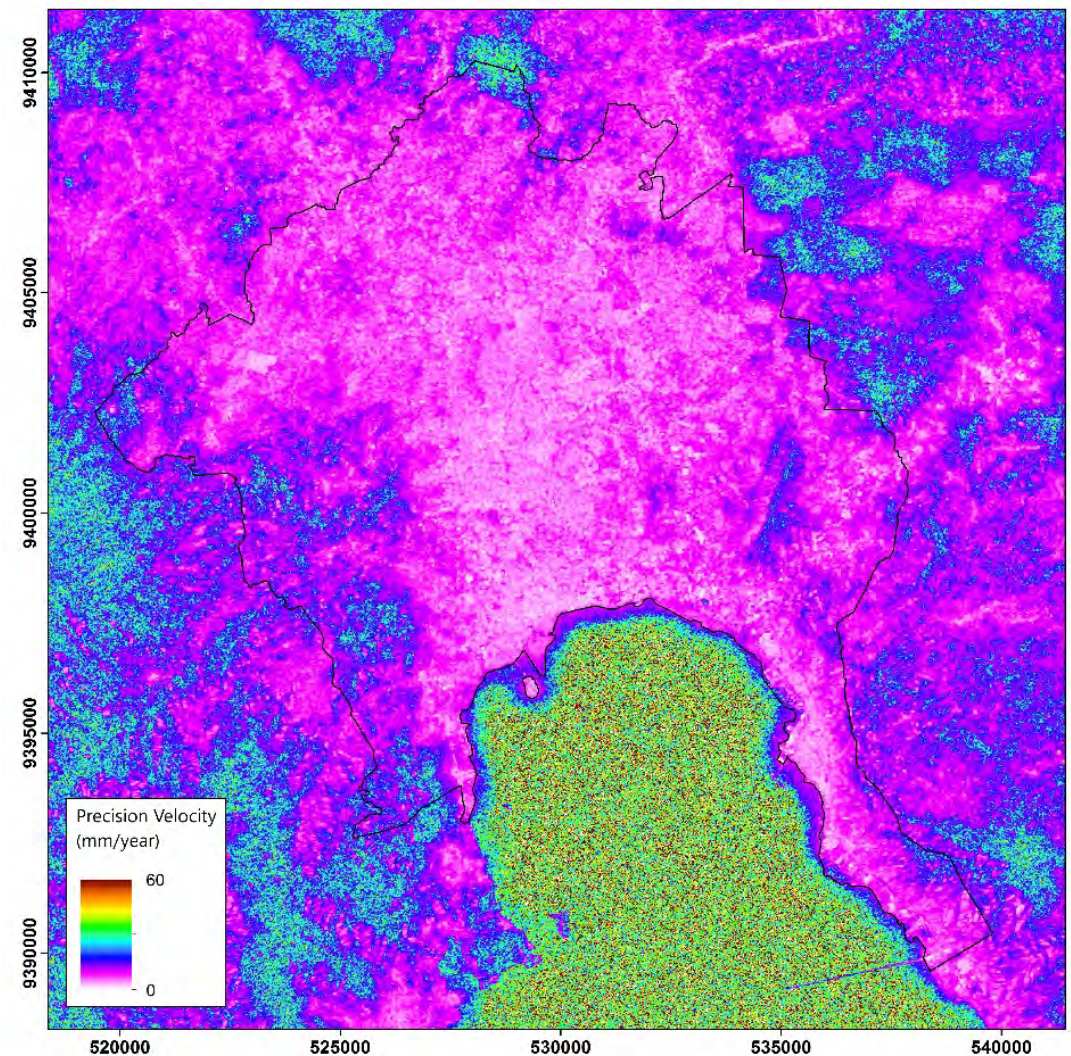

Gambar 4. Precision velocity map. 


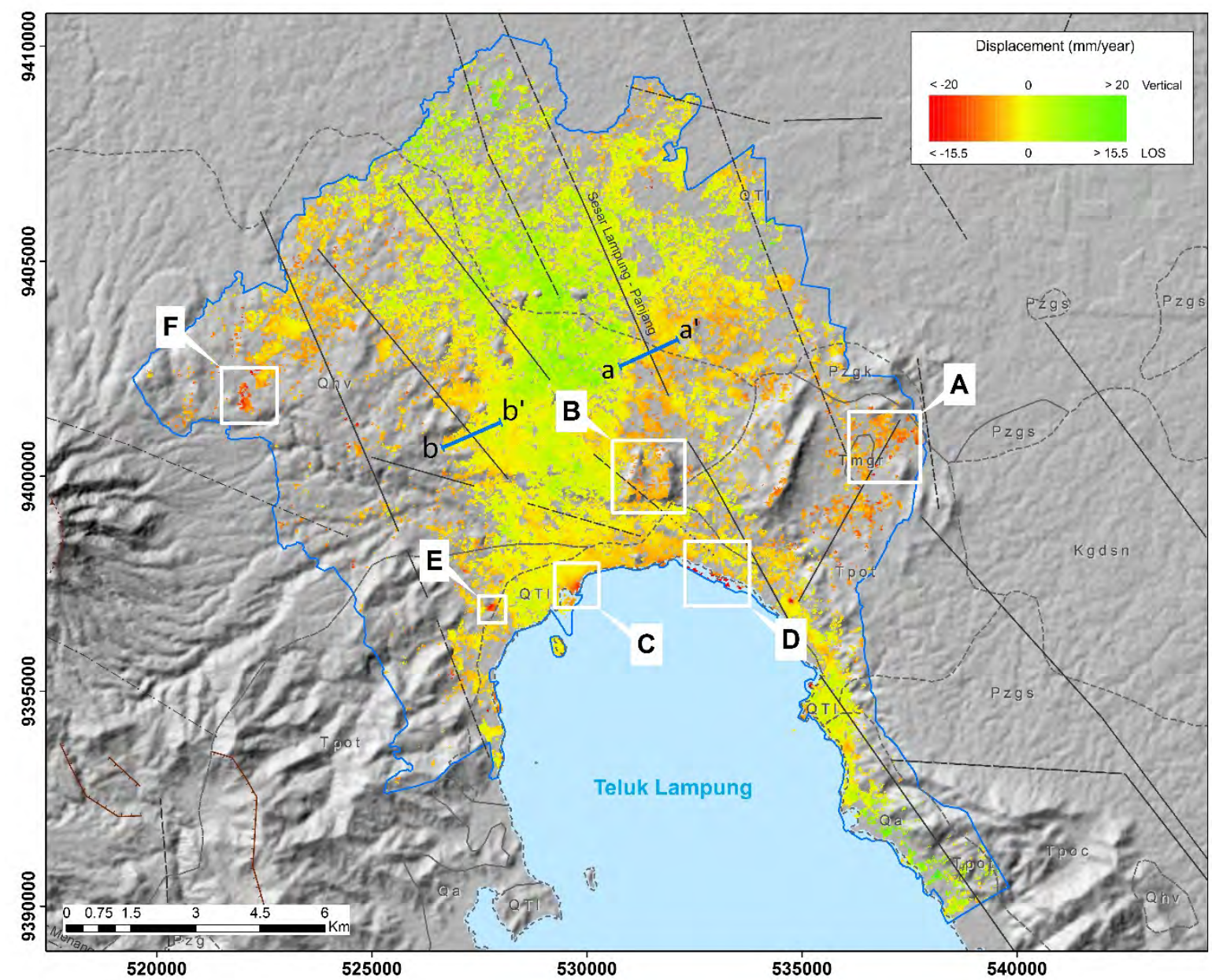

Gambar 5. Penampalan data geologi regional terhadap data penurunan muka tanah. Batas litologi ditunjukkan oleh garis putus-putus berwarna abu-abu, struktur geologi ditunjukkan oleh garis berwarna hitam, garis transek ditunjukkan oleh garis biru, dan daerah observasi direpresentasikan oleh kotak putih.

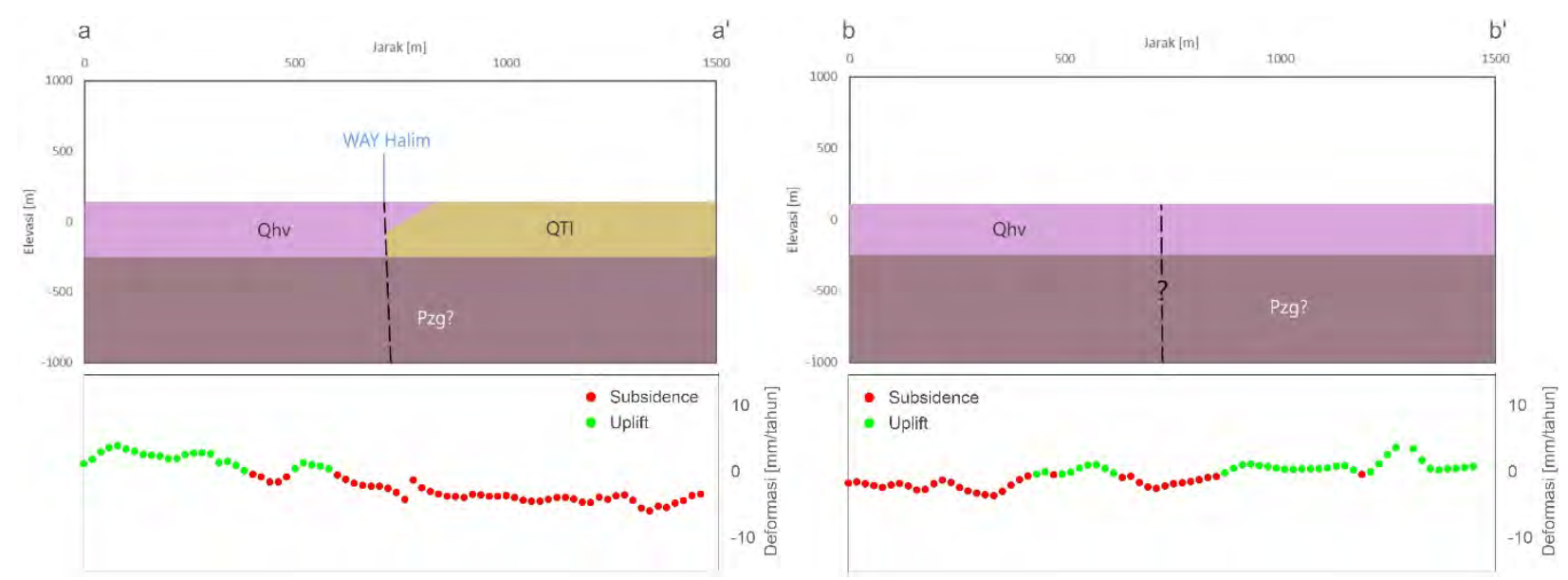

Gambar 6. Transek geologi dan kecepatan deformasi pada profil a - a’ dan b - b’. 


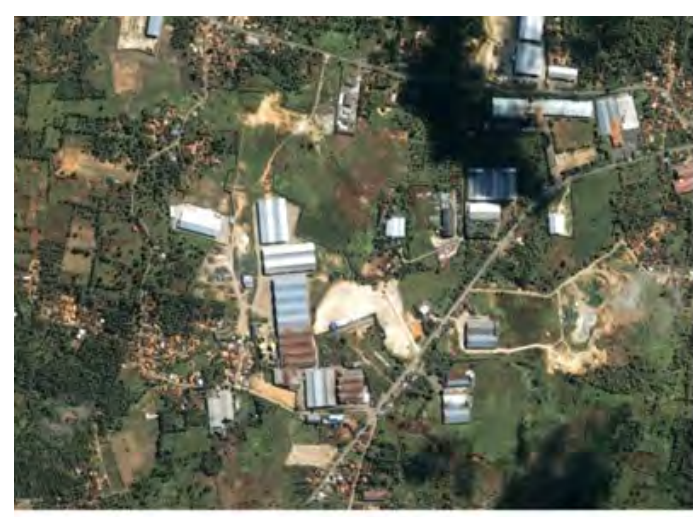

(a)

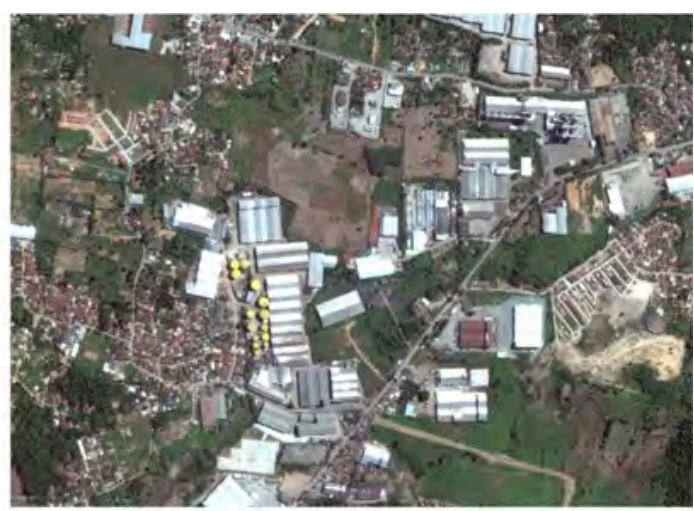

(b)

Gambar 7. Perkembangan kawasan industri di Campang Raya. (a) 7 Desember 2001. (b) 5 Desember 2012.

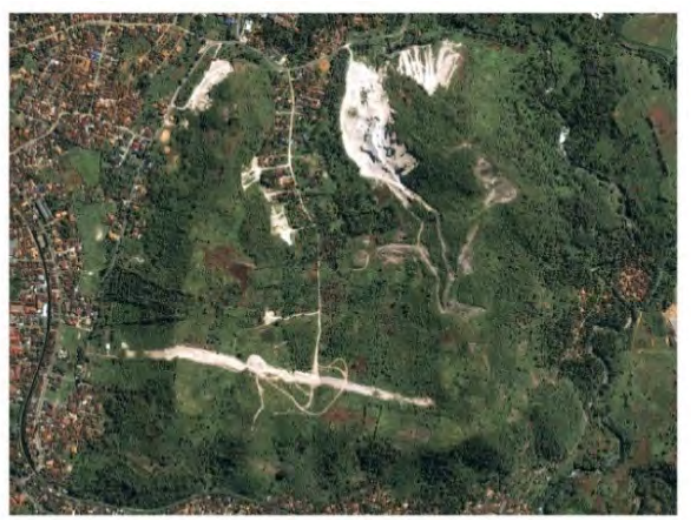

(a)

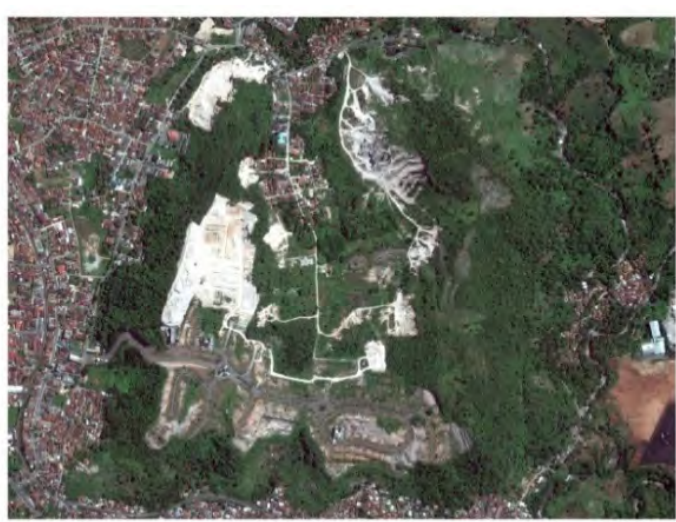

(b)

Gambar 8. Kondisi Gunung Camang yang mengalami konversi lahan; (a) 7 Desember 2001. (b) 5 Desember 2012.

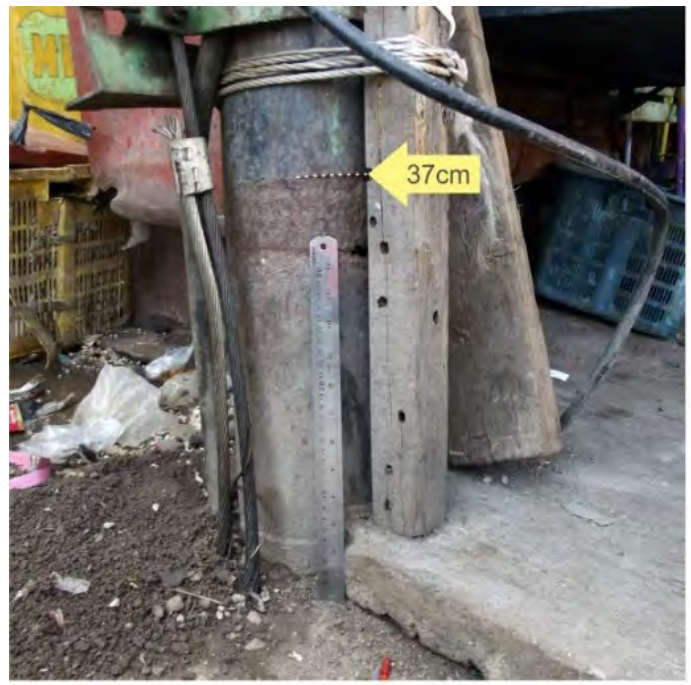

(a)

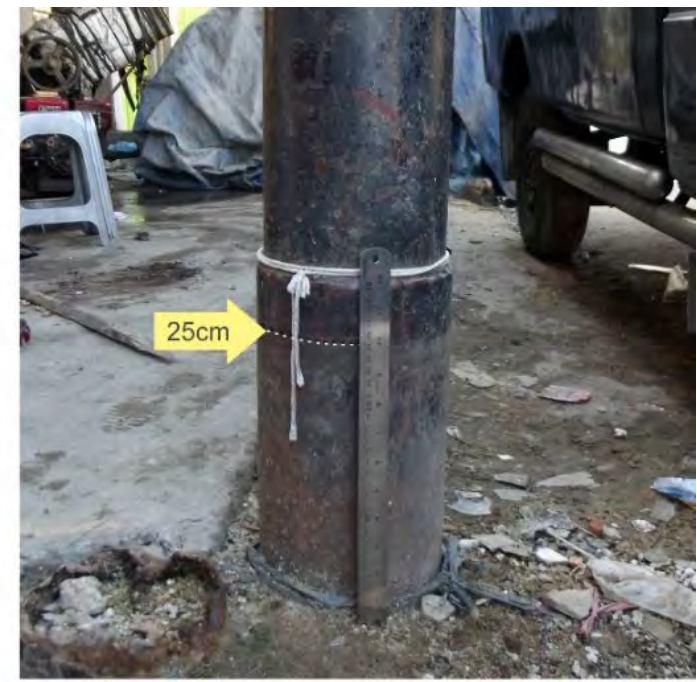

(b)

Gambar 9. Indikasi penurunan muka tanah pada tiang listrik di sekitar Pasar Kangkung; (a) Jarak 100 m dari garis pantai. (b) Jarak 150 m dari garis pantai. 

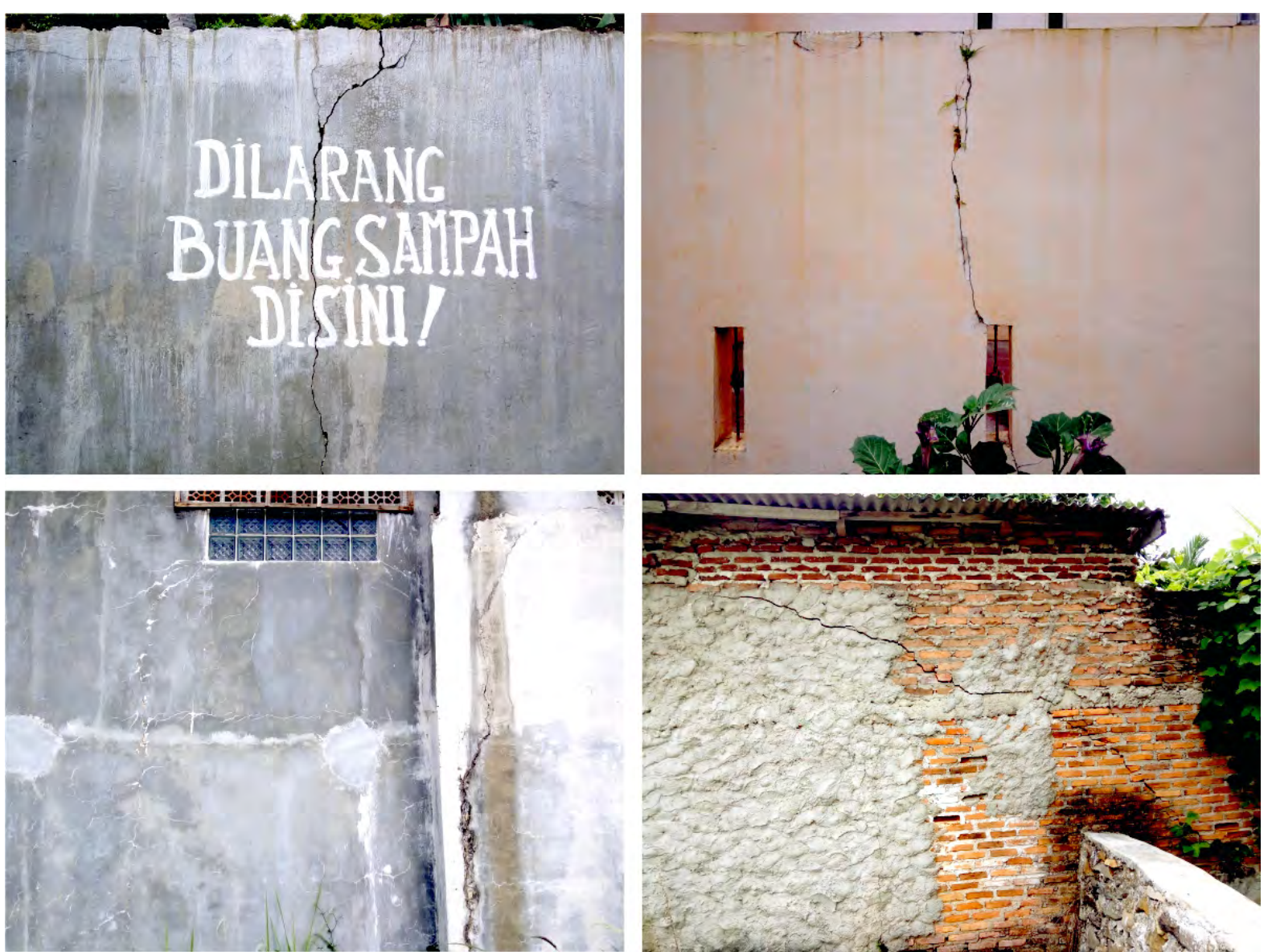

Gambar 10. Beberapa satu sempel kerusakan struktur bangunan akibat penurunan muka tanah di Daerah Bakung, Telukbetung Barat.

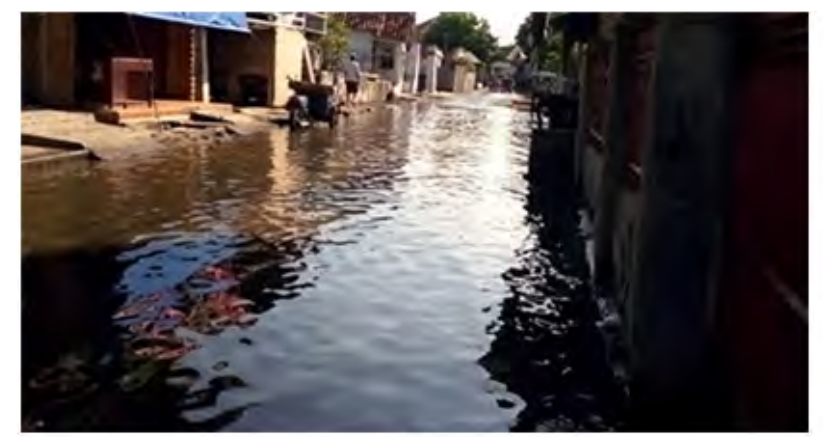

(a)

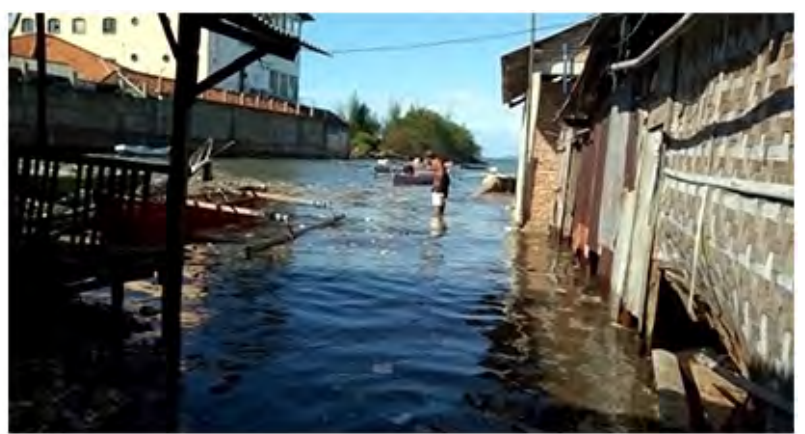

(b)

Gambar 11. Banjir rob di pesisir Bandar Lampung. (a) Kelurahan Sukaraja, Rabu 8 Juni 2016. (b) Jalan Teluk Bone, Kota Karang, Senin 6 Juni 2016. 